Stone, I.R. 1985. Charles Codrington Forsyth (ca. 18101873). Arctic 38 (4): 340-41.

Stone, I.R. In press. An episode in the Franklin search: the 'Prince Albert' expedition, 1850. Cambridge: Scott Polar Research Institute Polar Monograph 2.

\section{The cultural impact of AIDS in the circumpolar north}

\section{E. Cruwys}

Scott Polar Research Institute, University of Cambridge, Lensfield Road, Cambridge CB2 1ER

\section{Mark Nuttall}

Department of Human Sciences, Brunel University, Uxbridge, Middlesex

Received June 1992

One of the most pressing contemporary concerns regarding the future health of northern communities is the spread of AIDS. Unlike Europe, the United States, and Africa, the introduction of HIV and AIDS in circumpolar regions is relatively recent. The first HIV-positive cases were diagnosed in Greenland in 1984, and, so far, there have been three deaths from AIDS-related diseases in Greenland, and several cases of AIDS in indigenous populations in Alaska and Canada. In 1991, 13 people were newly diagnosed HIV-positive in Greenland, including seven women. Currently, there are 37 people who are HIV-positive in Greenland, and five cases of AIDS. Most of these people contracted the virus by heterosexual transmission (Greenland Medical Council 1991). Although these figures may seem relatively insignificant compared to statistics from, for example, Africa, the total population of Greenland in 1991 was 55,533 (Grønlands Statistiske Kontor 1990), which gives a ratio of one HIV-positive case to every 1,500 individuals.

Evidence from historical accounts of early encounters with northem peoples suggests that venereal diseases already existed in indigenous populations prior to westem contact, but there is no documentary evidence to give an indication of the extent or frequency of outbreaks. Currently, native peoples who inhabit the circumpolar north from Siberia to East Greenland already have a high incidence of other sexually transmitted diseases (STDs). Corresponding to this is potential for rapid transmission of HIV and the possibility of an AIDS epidemic in the north. This situation was discussed at the Circumpolar Meeting on AIDS Prevention in Ilulissat, Greenland, in September 1989. Reports were given on norms in sexual behaviour, the prevention of HIV infection, and the incidence of other STDs. The initial success of anti-AIDS campaigns, such as the STOP-AIDS campaign in Greenland in 1986 and 1987, was also noted.

There is growing recognition that anthropological expertise and research is needed to supplement medical research in order to contribute to an awareness of the cultural factors and sexual norms that increase the risk of spreading HIV in the Arctic. As in other parts of the world, there is a problem with the effectiveness of campaigns that do not address themselves to specific cultural contexts. But AIDS-related diseases do not only threaten life itself, they engender a cultural response that has severe implications for how people with the illness perceive themselves and are perceived by others within their society.

In the United States, AIDS has become a pejorative metaphor that tends to victimise those who have developed the illness. In this way, the wider society generally places the responsibility for the cause of AIDS on the individuals themselves. The moral implications used to label AIDS sufferers give rise to social and economic discrimination and isolation of the individual. Discussion of AIDS and other STDs occurring in the Arctic tends to lead to the labelling of indigenous peoples, such as the Inuit, as promiscuous. The irresponsibility of the individual is moralistically judged as the cause, and the external perceptions of promiscuity tend to obscure cultural meanings regarding sexual behaviour. While the threat from AIDS is not to be ignored, the effect of moralistic AIDS discourse could result in social and cultural conflict, prejudice, and social fragmentation in small northern communities.

In order to resist the deleterous effects of this process, it is necessary to embark on a programme of re-education. It is widely accepted that AIDS sufferers require counselling as well as medical treatment in order to come to terms with their illness. It is important that such counselling should be culturally sensitive, both to the AIDS sufferers and their carers. Likewise, planned anti-AIDS and STD campaigns are more effective if the social and behavioural norms of the people at which they are aimed are borne in mind. Essentially, the messages of AIDS campaigns have usually urged changes in sexual behaviour, such as having fewer sexual partners. However, this carries a negative moralistic message that is inappropriate to the sexual norms of some communities, despite its success in other cultures.

In any small community, a person suffering from a potentially fatal and potentially contagious disease can produce a conflict of interests, particularly where external messages have led to stigmatisation being attached to the illness. It is clear that campaigns and counselling should be aimed at the community as a whole, not only at AIDS sufferers and their immediate carers; tolerance and compassion become particularly meaningful in small, isolated groups, where social barriers may cause the destruction of the cultural integrity of a community.

The spread of HIV and the development of AIDS in the circumpolar north illustrate how the recent past, and certainly the future, of native peoples is inextricably bound up in a wider world context. There has been a considerable increase in social research focusing on the ideological and economic assimilation of native peoples into the mainstream of nation states, and the study of health and disease reveals the deleterous effects of this assimilation. The introduction of new diseases and the severity of epidemics has undermined the social and spiritual fabric of native 
life. Yet, while large-scale devastation of communities in the north is a thing of the past, new illnesses, such as AIDS and various degenerative diseases, may precipitate a reflexive crisis for the individual and the community. By interpreting and coming to terms with such illnesses, the individual will become involved in a re-definition of self that may, in turn, reflect the attitudes of a wider society.

\section{References}

Grenlands Statistiske Kontor. 1990. Statistisk Arbog. Ukiumoortumik kisitsisitigut paasissutissat. Nuuk: Grenlands Statistiske Kontor.

Greenland Medical Council. 1991. Sundhedstilstanden i Gronland Arberetning for 1991. Nuuk: Landslaegeembedet.

\section{Obituary}

James Herbert Zumberge, geologist and former president of the University of Southern California, died in Pasadena, California, on 15 April 1992 at the age of 68. A native of Minneapolis and a former Marine Corps lieutenant, he received his bachelor's degree and doctorate from the University of Minnesota. While teaching at the University of Michigan, he led the US Ross Ice Shelf Project during the International Geophysical Year, 1957-58. The reasoning behind the project was that a deforming ice shelf should, in the space of a year, serve as an analogue for millions of years of deformation in rocks. Summer field work continued under his direction until 1962, yielding significant scientific results and $\mathrm{PhDs}$ for his students.

A bom leader, Zumberge was selected from hundreds of professors in 1962 to be first president of Grand Valley State College in western Michigan. This involved designing a campus to fill what was then a green field site, raising tens of millions of dollars, and, finally, attracting good teaching and research staff and students. Achieving these goals in under two years launched him into a new career as president of successive universities of ever greater prominence, culminating in the presidency of the University of Southern California from 1980 until his retirement in 1991. He raised $\$ 641$ million for new developments at USC; to the fame of its athletic department, he added academic excellence.

He maintained a lifelong interest in Antarctic affairs, serving as US delegate to the Scientific Committee on Antarctic Research (SCAR) 1972-86, and president of SCAR 1982-86. He was adviser on Antarctic affairs to the US State Department 1970-73, was appointed by President Gerald Ford to the National Science Board in 1974, and was selected by President Ronald Reagan to chair the Antarctic Research Commission in 1984. At the same time, the Governor of Califomia appointed him to the state Economic Development Commission.

Zumberge's textbook Elements of geology (1958) established his position as a teacher at the same time as the Ross Ice Shelf work established his credentials in polar research. An exceptionally competent educator and administrator, he had the knack of delegating responsibility to those he trusted, and his staff responded with loyalty and devotion. He seemed effortlessly to bridge the gulf that often divided academics from businessmen and govern- ment. As a result, he was appointed to the board of a number of large corporations. A keen sportsman, he was a good skier and a formidable opponent at water polo. His friends in many lands will remember Zumberge's infectious sense of humour and his great skill at the piano, often a focal point for social gatherings at SCAR meetings and elsewhere.

He received six honorary degrees, and, in Antarctica, Cape Zumberge and the Zumberge Coast are named after him.

\section{Charles Swithinbank}

Harold Victor Serson, Canadian Arctic specialist, died in February 1992 at the age of 66 during a holiday in Costa Rica, where he suffered a heart attack while swimming. He was born in Ottawa in February 1926. On leaving high school in 1944, Serson's first job was as a seaman in the Hudson Bay Company ship Nascopie, operating in the eastern Arctic. In 1947 he joined the technical staff of the Radio Propagation Laboratory of the Defence Research Board (DRB), becoming the following year one of the first people to overwinter at the DRB's Ionospheric Station at Resolute, Cornwallis Island, which he helped to establish. Until 1963 Serson continued to work in the radio propagation field for the Defence Research Telecommunications Establishment in Ottawa, apart from a year spent at the DRB's Radar Laboratory in Prince Albert, Saskatchewan. He was promoted from technician to technical officer in 1956.

Early in 1961 Serson and the late Trevor Harwood (Polar Record 22 (140): 555-56, 1985) were flown in to investigate the abandoned Soviet ice station NP-7, which had drifted down from the Arctic Ocean through Nares Strait to a position off the east coast of Baffin Island. He and Harwood were an ideal pair to make a full report on the station, with their highly inquisitive minds, the one geared to technical and the other to intelligence matters.

In 1962 Serson transferred to the DRB's Geophysics Section, which was then establishing a new field station at the head of Tanquary Fiord, northem Ellesmere Island. In ensuing years he was the mainstay of the oceanographic work on the ice of the fiords of northwest Ellesmere Island and of the west coast of Axel Heiberg Island. Much of the trail equipment for the long traverses over the ice by 